\title{
Dyreliv bak låste dører
}

\author{
At gårdsfolk er glade i husdyrene sine, er selvsagt. Og forholdet folk flest har til sine kjæledyr, \\ kan være preget av dyp og ekte kjærlighet. Men at det kan være gjensidig vennskap mellom \\ forsker og forsøksdyr, er en overraskelse for mange.
}

Filosofen Arthur Schopenhauer (1788-1860) var en særlig venn av hunder. En gang skal han ha uttalt følgende: «Jo mer jeg lærer menneskene å kjenne, desto mer høyakter jeg min hund.» Rett nok var han kjent som misantrop og litt av en grinebiter, men utsagnet behøver ikke å bety at han nedvurderte mennesket. Til det var hans hundekjærlighet altfor dyp og ekte.

Det er mindre kjent at forskere kan bli nær knyttet til forsøksdyrene sine. Et nært og godt forhold til eselet Jeanette, som ellers var ganske vrang og ingen andre av staben ville ha, var viktig for et stort medisinsk fremskritt den norskamerikanske mikrobiologen Konrad Birkhaug (1892-1980) sto for i USA i 1920-årene. Det gode forholdet var nemlig en forutsetning for at han klarte å immunisere eselet med gjentatte injeksjoner av en bestemt type streptokokker. Slik fremstilte han et antiserum som var det første effektive midlet mot den farlige hudsykdommen erysipelas (rosen) - og ble berømt.

I atskillige år har jeg arbeidet med hjernekreft, med problemstillinger omkring utvikling og spredning. Det begynte i 1971 mens jeg bodde i Tyskland. Til forsøkene benyttet vi en bestemt type brune rotter. Etter at jeg hadde flyttet tilbake til Oslo og skulle fortsette eksperimentene, fikk jeg noen avlspar av rottestammen av den kjente forskeren Hermann Druckrey (1904-94) i Freiburg. Han hadde selv avlet dem frem. Da jeg hentet rottene, fikk jeg dem overrakt av den store forskeren personlig - og på ett vilkår: Jeg måtte gå ned på dyrestallen hver dag og snakke med dem! Det gjorde jeg også, og de svarte ved å lage smattelyder. Ved rottefors $\varnothing$ k som går over flere år, har jeg sett at enkelte forskere begynner direkte å likne på dyrene sine og ha samme mimikk.

For flere tiår siden var dyrestallene gjerne åpne, og det kunne være så som så med renholdet. Hvem som helst fikk komme inn etter avtale. Forskernes barn var hyppige gjester, inklusive mine egne. Epidemier herjet blant dyrene, og det kunne ødelegge store forskningsprosjekter. Krav om strengere kontroll kom ikke bare fra veterinærer og forskerne selv, men også fra dyrevernere. Noen av dem mente at forskerne drev systematisk dyreplageri. Særlig i England var det en rekke aksjoner mot dyrestaller. De militante dyrevernerne skjønte ikke at det ofte var et nært personlig forhold mellom forsker og fors øksdyr.

Siden kom det nye lover og forskrifter om bruk av fors $\varnothing$ ksdyr, og det skjedde en innskjerping av sikkerhetsreglene for å unngå infeksjoner. Immundefekte dyr kunne dermed holdes rimelig trygt. Men da måtte personalet dusje og skifte før de fikk lov til å gå inn til dem. Artikkelen under ble skrevet i en periode med sterk internasjonal motstand mot dyrefors $\varnothing \mathrm{k}$ og innføring av strenge regler og kontrollordninger. Hensikten med artikkelen var å vise det personlige forholdet til dyrene, der forskeren kunne gå Schopenhauer en høy gang. Ble sikkerhetsreglene for strengt praktisert, kunne det gå på bekostning av dette forholdet.

I dag er forsøksdyr en spesiell oppgave for høyt kvalifiserte veterinærer og laboranter, dyreholdet er teknisk avansert og fungerer godt. På en måte er artikkelen min derfor totalt foreldet - eller historisk. Det kan likevel hende at forskeren ikke får utfolde sin personlige kontakt med mus og rotter slik som tidligere. Professor i rettsmedisin i Bergen, Inge Morild, som har arbeidet med flere typer forsøksdyr, har tegnet dem med kjærlig penn. Ellers kan jeg gå god for at alle historiene i artikkelen er sanne.

\section{Ole Didrik Lærum}

ole.laerum@gades.uib.no

Ole Didrik Lærum (f. 1940) er professor (adj.) ved Københavns Universitet og professor emeritus ved Universitetet i Bergen.

\section{OM MEGAMUS OG MENN}

Lærum, OD: Om megamus og menn. Scand Las NYT 10: 1-11, 1983.

Av Ole Didrik Larum, Gades Institutt, Avdeling for patologi, Universitetet i Bergen, 5016-Haukeland Sykehus.

Med tegninger av Inge Morild

\section{Flyfroskene}

En forsker som drev med frosker skulle bringe en ladning forsøksdyr fra New York til England, hvor han arbeidet. De hadde en sjelden transplantabel svulst og var derfor særdeles verdifulle til undersøkelser over svulstspredning. Han ankom J. F. Kennedy flyplassen i New York og meldte seg ved skranken til flyselskapet BEA, avleverte billett og bagasje og meddelte samtidig at han hadde noen frosker i håndbagasjen. Damen bak skranken skrek opp og rullet med øynene: «Frosker på jumbojet'en? Aldri i verden! Det får være måte på frekkhet.»

Den arme forsker prøvde å forklare, men etter kort tid sto han med både bagasje, 
billett og froskeboks i hånden. Flyet lettet. Nokså slukøret tuslet han bort til PAN AMskranken for å gjøre et nytt framstøt. Der skulle neste transatlantiske fly gå om et par timer. Han leverte billetten og ba om å få den forandret til dette flyet, leverte bagasjen, trakk pusten dypt og sa: «I tillegg har jeg noen meget verdifulle forsøksdyr til vitenskapelige undersøkelser innen kreftforskning, som jeg gjerne ville ha $\mathrm{i}$ håndbagasjen.» «Det var da meget interessant», sa damen bak skranken. «De må da så gjerne ta dem med inn i kabinen så det ikke tilstøter dyrene noe. Ha en riktig god reise.»

Forskeren og froskene tilbrakte en velsignet flynatt. Dyrene kvekket diskret i ny og ne så enkelte passasjerer snudde seg. Forskeren kremtet og rødmet. Passasjerene roet seg igjen, idet de antok det bare var noe ulyder fra magen til medpassasjeren, på grunn av det særdeles rikholdige jumbojet-måltidet.

\section{Dyrenes forfremmelse}

Dermed er vi inne på et sentralt emne i moderne biomedisinsk forskning. Her beskyldes man for å drive utstrakt dyreplageri i forskningens tjeneste. Virkeligheten er da ganske motsatt. Å bli forsøksdyr er en stor forfremmelse for en hvilken som helst mus, rotte eller frosk, - ja til og med bissevover og smådyr. Fra å leve en kummerlig tilværelse ute i naturen eller hos tilfeldige eiere, blir de tatt hånd om på den aller beste måte på moderne dyrestaller. De omfattes av et særdeles strengt regelverk som fastslår i detalj hva man har lov til å gjøre med dyrene og hvilken framgangsmåte som brukes. På mange måter er reglene for hva man kan gjøre med forsøksdyr strengere enn hva man kan gjøre med sine medmennesker. I tillegg vil hvert eneste dyr bli omhyggelig registrert og innrapportert til departementet. Bortsett fra at de mangler navn, figurerer de med personnummer som i det fineste folkeregister. Godt og trygt lever de. Mat får de hele døgnet, vann når de ønsker, og temperatur og fuktighet er regulert som i den fineste norske dagligstue, ja kanskje ennå bedre.

I motsetning til den blodige grusomhet ute i naturen, får de leve et langt og trygt liv i de fineste småleiligheter, $i$ spesiallagede dyrebur. Skal noe smertefullt skje, blir de omhyggelig bedøvet og passet på. Skulle forsøket føre til lidelser, så er ikke det så kjekt, men jeg våger likevel å påstå at de lidelser vi ser hos pasienter med langtkomne sykdommer på våre sykehusavdelinger kan være betydelig verre.

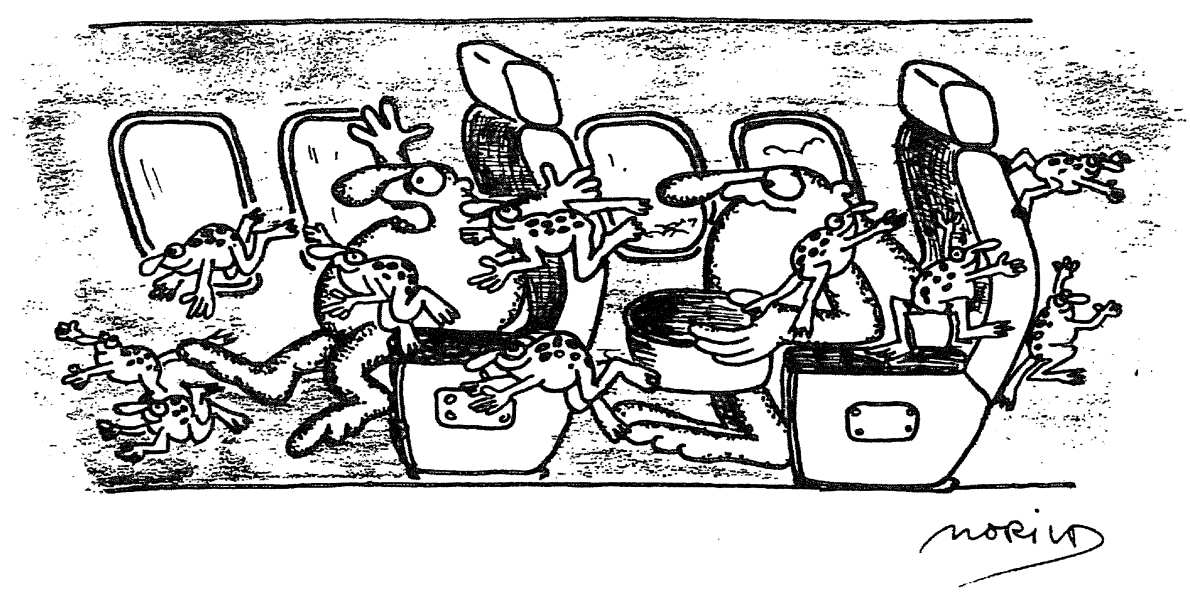

Fig. 1. Froskene kvekket muntert på jumbojeten og hadde riktig utbytte av reisen.
Og så blir man glad i dem. Personlig har jeg et meget nært forhold til rotter. Etter over 10 års samarbeide med BD-IX rotter som en særlig vakker avart av den norske rotten (Rattus norvegicus), er jeg blitt en dyp beundrer av dette dyr.

\section{Medaljens bakside}

Sjølsagt har medaljen en bakside. Den har opp til flere, og hverdagen på dyrestallene er ikke alltid så lys og smilende som man kan få inntrykk av. Ofte er dyrene trangbodde, og de mangler kontakt med den frie naturen.

Mus og rotter har blitt store salgsartikler. De produseres og selges i tusentall som om det skulle gi løsningen på menneskenes sykdommer, og mange forskere tenker bare i mus og rotter.
Nei, her må det nytenkning til. Hvorfor tar man ikke litt mer fra de mange andre arter i dyrerekken? Frosker kvekker da så koselig, og spretter gjør de så det monner. Tenk hvilke overraskelser og muntre episoder det ville medføre å gjøre forsøk med en 10-15 sprettende frosker om gangen!

Skal man vite mer om mennesket kan det være bra å prøve på apekatter, men aller best er det å gå til grisen. Den skal være så utrolig lik på mennesket. Helt fra fosterstadiet. En særlig fascinerende avart er de såkalte minigrisene, som har under en tredjedels størrelse av normale griser. Tenk så mye koseligere det ville være å ha en ladning smågriser nøffende omkring på dyrestallene. Ja, jeg kunne tenke meg å invitere dem opp på kontoret mitt hvis de viste seg å være av den omgjengelige sorten. Både en liten datter og flere

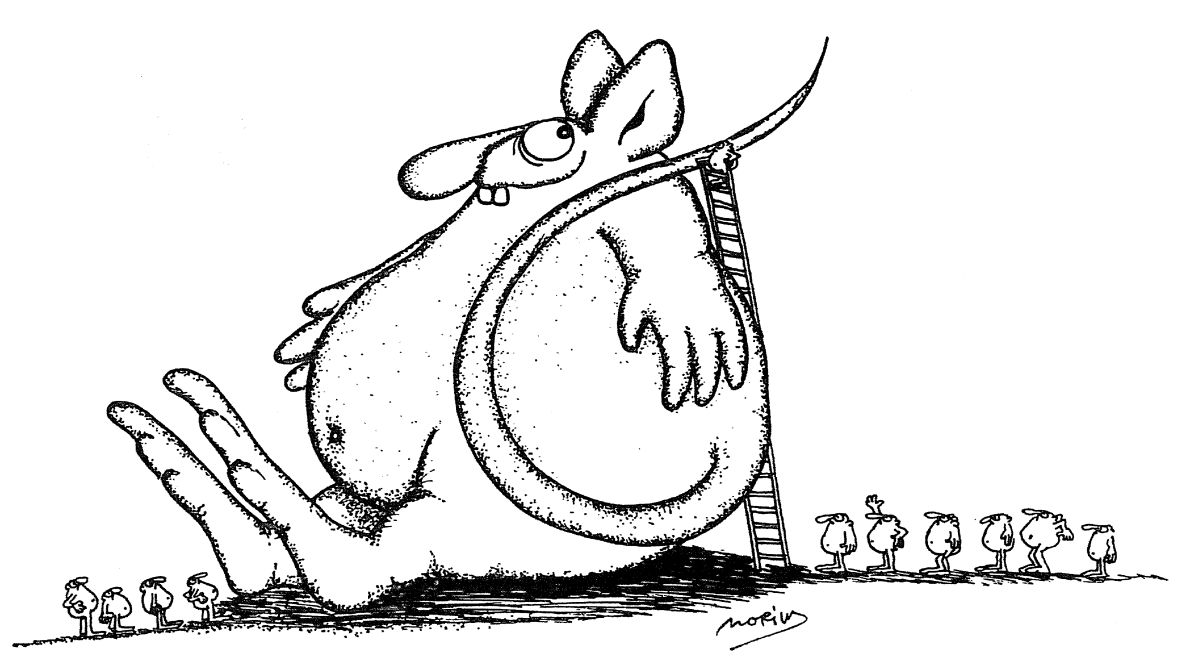

Fig. 2. Framtida ligger $i$ å forske på megamus. Kanskje vil det medføre overraskende resultater. 


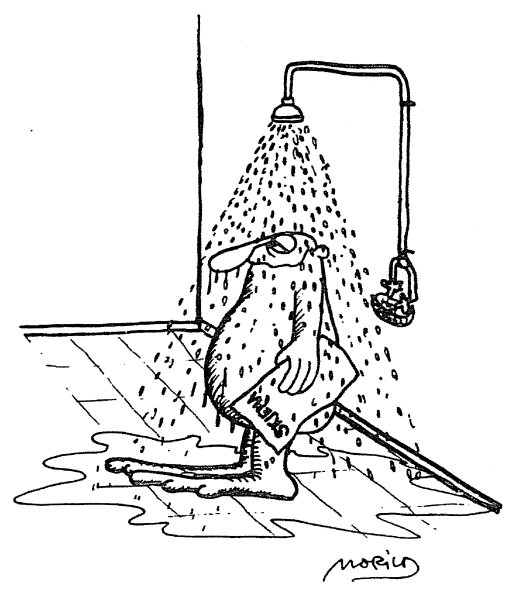

Fig. 3. A) Forskeradelen vil etter forutgående vask av beina og søknad i 3 eksemplarer til de høyere makter få gå inn og gjøre dyreforsøk.

nieser har spurt om jeg ikke kan skaffe dem en smågris til å ha i sengen og kose med. Motsatt kan man i dag putte et par rottegener inn i muse-embryoner, og derved vokser de opp til kjempestørrelse: De har allerede fått navnet »supermouse«. En annen god idé måtte være å fjerne hypofysen på nyfødte flodhester og elefanter, slik at de fikk sånn passe størrelse til et stuedyr av den koselige sorten. Uten veksthormon ville de jo forbli små og søte og kunne passe overalt. Hvem kan vite om ikke flodhestens biokjemi og blodsirkulasjon er vel så interessant som musenes. De måtte også være et utmerket forskningsobjekt til å studere hvordan rynker i huden oppstår. I det hele tatt er det skuffende hvor svakt både elefant- og flodhestforskningen står for tida, både nasjonalt og på verdensbasis.

Det eksisterer også en rekke interessante dyrearter som hittil ikke har hatt den ære å bli til laboratoriedyr. Det gjelder både gnu og vicunia, mens den lille søte gerbilen såvidt har vært påaktet av et par hjerneforskere. Her fins det fine muligheter til attføring av arbeidsløse rotteforskere; ja, for en gang må vel rotten være ferdig utforsket.

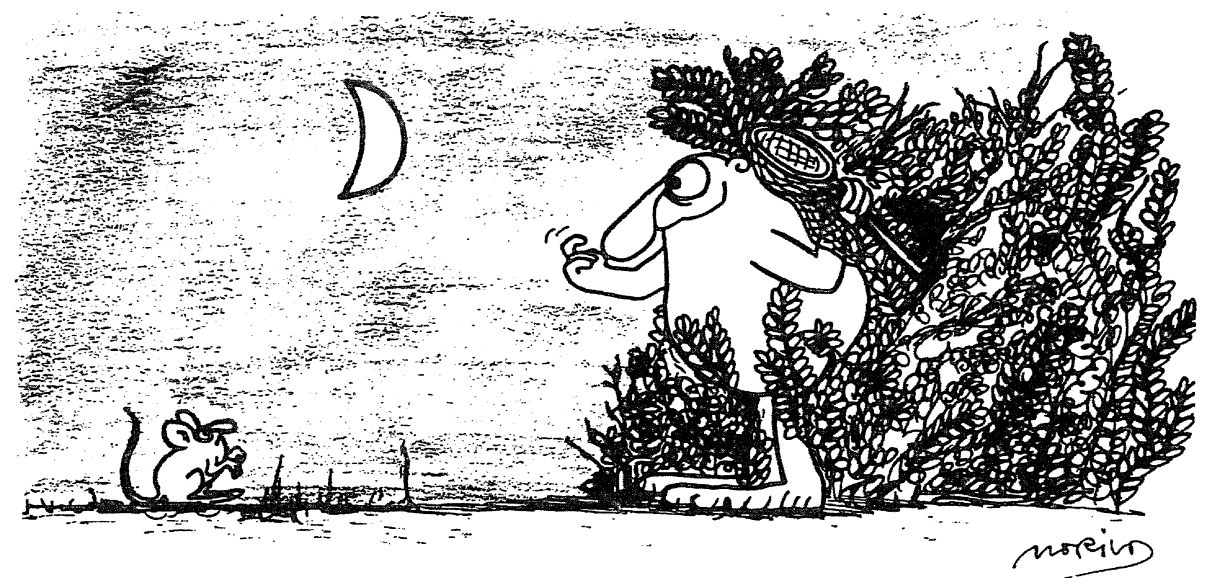

B) - mens pariakasten må ligge på lur bak en busk.

Laboratoriedyrenes isolasjon

De riktig fine forsøksdyrene holdes strengt isolert fra omgivelsene. Ville rotter og mus, som kanskje både fryser og er sultne $\mathrm{og}$ tørste må ingenlunde tillates å snike seg inn til sine fettere og kusiner i dyreburene. Riktignok har det vært nære på et par ganger på dyrestallen til gamle Gades institutt, men det var fordi villdyrene ikke visste bedre. Det er absolutt ikke tillatt.

Mennesker har strengt tatt heller ikke tillatelse til uten videre å gå inn på dyrstaller. Ja, til og med hvis man har tillatelse, må man både dusje, vaske håret og skrubbe beina før man får lov å komme inn til de aller fineste dyrene, de adelige musene som kan sette tittelen SPF etter navnet. Jeg hørte om et sted der det ble forbudt å gå inn på dyrestallen etter klokka 15, innbefattet dem som skulle gjøre forsøk, for da skulle dyrene ha ro. Veterinæren også.

Heller ikke er det lov til å ta i en mus eller rotte uten uttrykkelig skriftlig tillatelse fra høyeste hold etter forutgående søknad i flere eksemplarer. Den arme forsker må også være sikkerhetsklarert og godkjent til

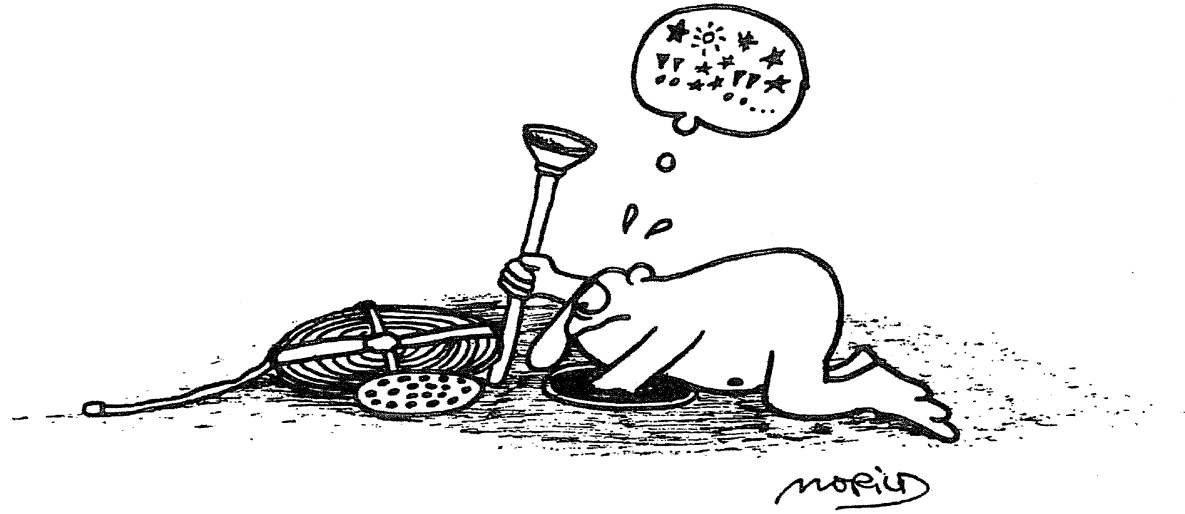

Fig. 4. Forskeren satt halve natten og prøvde å få tak i den forbaskede musa som stadig forsvant nedi sluket. slikt, og hver eneste mus må være omhyggelig nummerert.

For ikke så lenge siden kom det en henvendelse til våre universiteter via Nordisk råd med oppfordring til å gjøre minst mulig dyreforsøk og fortrinnsvis gå over til forskning der man ikke trengte forsøksdyr. Meningen var god, men de var åpenbart lite kjent med at moderne vevkulturteknikk allerede har overflødiggjort tallrike dyreforsøk for lenge siden. Hvis en slik utvikling skal fortsette til det ekstreme, ser jeg for meg en framtid der forskerne blir delt inn i to slag. Det er de med og uten tillatelse. De førstnevnte er de adelige som etter forutgående vask av beina får aller nådigst lov til å gjøre dyreforsøk. Det blir forskningens noblesse. Den andre kategorien, pariakasten, er de forskerne som ikke har fătt tillatelse. Skal de gjøre dyreforsøk, må de snike seg ut i nattens mulm og mørke, kanskje sitte i timesvis på lur bak en busk for så å kaste seg over en tilfeldig forbipasserende rotte. I heldigste fall blir utbyttet nok til å gjøre et lite forsøk.

\section{Internasjonal kappforskning}

Vi lever i kapprustningens tidsalder. Raketter, stridshoder og bomber måles i kilo og megatonn TNT. Kjemisk krigføring reknes imidlertid ikke for fullt så gjevt. Det foranlediget den forrige amerikanske president til å nedlegge et av de større produksjonsstedene for stridsgasser og bakteriologiske våpen. Senteret lå dypt hemmelig langt inne i en skog på et sted som heter Jefferson i Arkansas. Hva skulle de så gjøre med alle de ansatte? I stedet for å arbeide med menneskehetens utslettelse, ble senteret omdannet til et gigantisk forskningsinstitutt for miljøtoksikologi. Deretter fulgte en enorm investering $i$ alt mulig slags avansert laboratorieutstyr, og så var det bare å sette i gang. Men med hva? I tillegg til en rekke andre prosjekter fant de på å gjøre verdens største museforsøk. Det besto i å gi musene svært 
små doser av et kreftframkallende stoff for å se om det fantes noen nedre grense for kreftframkallende virkning. For å få en slik undersøkelse til å bli statistisk pålitelig, var det nødvendig med et stort antall dyr, noe andre institutter aldri hadde hatt råd til.

Altså satte de i gang. I ett eneste forsøk brukte de 24.192 mus. Ganske riktig kom det fram at det var ikke noen sikker terskelverdi for kreftframkallende stoffer, og resultatene har hatt stor generell interesse.

Nå hadde de 4 mus i hver kasse, slik at de klarte seg med bare 6.048 musekasser. Dette heroiske fors $ø \mathrm{k}$ ble for ettertida innført som en egen enhet, en megamus.

Så langt har ingen klart å slå denne rekorden, og den absolutte overlegenhet finnes for tida «over there». Men bare vent, kanskje kommer det snart rapport fra supermakten som danner den ideologiske motpol at nå har vi nådd opp i to megamus. Hva med Frankrike? De kan da ikke være dårligere. Kanskje klarer de 5 megamus i løpet av 1980-årene. Så nå ligger det an for en kappmusing av rang. Her i Norge må vi nok nøye oss med et par kilomus i ny og ne, så vi bør vel øke vår styrke ved å slå oss sammen med andre land.

Når de virkelig store statene går inn for de virkelig store dyreforsøkene, feies alle regler og byråkratiske bestemmelser til side. Her trengs ingen søknader i tre eksemplarer, for landets ære og sikkerhet står jo på spill. Hva så med den lille forsker? Jo, han får nøye seg med den lille mus, stryke den pent over pelsen og si at han er glad i den. Kanskje blir utfallet så tragisk som det var for en kollega i Oxford, som hadde gjort et særdeles kostbart og vanskelig eksperiment på noen få mus. Alle døde untatt en, men han reknet med at resultatet likevel ville bli så signifikant at forsøket hadde verdi. Seint på kvelden var han ferdig og skulle kaste et siste blikk inn i musekassen.
Der var musa søkk borte. Plutselig pilte den foran beina hans og vips i et sluk midt på golvet. Han kastet seg ned på kne og strakk armen langt ned i sølevann og guffen gjørme. Han fikk musa opp igjen, men så skvatt den nedi sluket på nytt. Musejakten fortsatte ut i de seine nattetimer. Til slutt klarte han å få tak i den våte, pjuskete og forskremte musa. Med skjelvende hender pakket han den godt inn i cellestoff og la den pent på en deilig liten seng i kassen sin. Forsøket var reddet, og han gikk heim for å få noen timers søvn. Da han neste morgen skulle se til sin lille venn, tenk så var den død.

\section{Litteratur}

Y. Shinoluzra, C. li. Frith \& D. L. Greenman: Correlation of urothelial characteristics with the development of bladder carcinomas in BALB/C female mice administered 2-acetyl-aminofluorene. Carcinogenesis 3: 615-619,1982. (Megamuseksperimentet).

J. G. Williams: Mouse and supermouse. Nature 300: 575, 1982. 